\title{
Blended Learning in a Paragraph Writing Course:
}

\section{A Case Study}

Anggri Muhtia, Suparno, Sumardi

Master Degree of English Education Department Universitas Sebelas Maret, Surakarta, Indonesia

Email: amuhtia@student.uns.ac.id

How to cite this paper: Muhtia, A., Suparno, S., \& Sumardi, S. (2018). Blended Learning in a Paragraph Writing Course: A Case Study. International Journal of Language Teaching and Education, 2(3), 206-216. https://doi.org/10.22437/ijolte.v2i3.5744

Accepted: October 18, 2018

Published: November 30, 2018

Copyright (c) International Journal of Language Teaching and Education.

This work is licensed under the Creative Commons Attribution International License (CC BY 4.0).

http://creativecommons.org/licenses/by/4 $.0 /$

\section{(c) ()}

\section{Abstract}

Blended learning, the instructional approach integrating online learning with faceto-face learning, is one of the approaches gaining widespread acceptance among educational practitioners. Combining the strengths of online learning and face-toface learning is believed to be able to enhance the quality of learning. Different subjects may have different designs of blended learning because there is no specific formula for the best practice of blended learning. This paper reports a study investigating the implementation of blended learning in a paragraph writing course. The purposes were to investigate the blended learning activities carried out in the paragraph writing course and to find out the extent to which it affected students' writing paragraph performance. The participants of this case study, who were selected purposively, involved one lecturer and six students of a paragraph writing class. The techniques for collecting data included interviews, observations, and document analysis, and data were analyzed using Miles and Huberman's interactive model. Ten blended learning activities, including five activities in face-to-face settings and five activities online, were identified in the course. The students' paragraph writing performance seen from the result of final test was satisfying, indicating that the use of blended learning had a positive effect on students' writing performance.

\section{Subject Areas}

Writing

\section{Keywords}

Blended learning, Face-to-face, Online, Paragraph writing

\section{Introduction}

Among four language skills, writing is apparently the most challenging skill for EFL learners. Zemach and Islam (2007) assert that writing is "one of the most difficult skills to master in both a first language and a second language" (p. iv). Students not only need to have adequate vocabulary to express their thoughts, but they also need to be attentive to grammar, spelling, punctuation, and capitalization. In addition, the students should make their pieces of writing unified and coherent to be understandable. For EFL students the complexity of mastering English writing skills is doubled with the fact that English is a foreign language. EFL students need to get exposed to 
the English language as much as possible and should be provided with sufficient writing activities and practices. The opportunities for students to get in touch with English and practice the writing skills in the class, however, are limited.

Advanced technology, especially the Internet technology, may provide such opportunities. One of the breakthroughs the Internet technology has established in education is the emergence of online learning. Through this learning channel, instructional activities can be performed outside the classroom time. Some teachers have fully used the online learning in their practices, but online learning alone is considered not sufficient because students have diverse learning preferences and some practical tasks cannot be performed online (Epignosis LLC, 2014). Thus, combining the online learning with face-to-face learning is seen a good choice because it combines the strengths of both learning channels to provide more learning opportunities that students need. Garrison and Vaughan (2008) emphasize that blended learning approaches are believed to be able to enhance learning experiences.

Several studies have investigated the implementation of blended learning in writing classes. Liu (2013) conducted a study at a university in Beijing investigating the implementation of blended learning in an academic writing course. The results showed the improvement of students' academic skill, the increase in student-student and student-teacher interactions, the decline in communication anxiety, and the development of learning autonomy. Tuomainen (2016) studied the implementation of blended learning in an EAP (English for Academic Purposes) course for academic writing and presentation skills in a Finland university. The study showed that the students favored blended learning in the course and appreciated the flexibility and convenience of blended learning. While both previous studies investigated the use of blended learning in academic writing, this present study investigated the implementation of blended learning in a paragraph writing course and it described the main activities in both learning channels in more detail which were not carried out in the previous studies. A detailed investigation about learning activities was intended to reveal the benefits and/or drawbacks of each activity that can be kept or should be improved. The aims of the study were to find out the blended learning activities in the paragraph writing course and to reveal the extent to which the use of blended learning affected students' paragraph writing performance.

\section{Literature Review}

\subsection{Paragraph Writing}

In academic writing, the goal of a paragraph is to support a claim or idea that helps build the whole purpose of the writing (Bryson, 2014). This implies that paragraphs play an important role in academic writing. Good paragraphing helps the reader understand the text because ideas need to be organized to make them make sense, and "keeping one idea to one paragraph is the most basic rule of good paragraphing" ("Best IELTS preparation", 2013). Zemach and Rumisek (2005) define a paragraph as 
"a group of sentences about a single topic" (p. 11), and the sentences explain the main idea of the topic.

Savage and Shafiei (2007) describe three elements of paragraph organization, namely the topic sentence, supporting sentences, concluding sentence. These elements should be unified and need to be organized coherently. These may not be easy as students could find it challenging to find ideas to include in their writing, and thus students need clear guidance, positive feedback, and interesting ideas to write about (Zemach and Islam, 2007).

\subsection{Blended Learning}

Blended learning is an instructional approach which combines face-to-face learning with online learning (Garrison \& Vaughan, 2008; Thorne, 2003; Macdonald, 2008). Different scholars, however, propose different concepts about blended learning. Garrison and Vaughan (2008) assert that blended learning is not an addition of online learning into face-to-face learning but "restructuring and replacing traditional class contact hours." Meanwhile, Thorne (2003) states that one learning type can be "a supplement to other types of training and learning" (p. 47). Among several models of blended learning in higher education identified by Twigg (2003), namely supplemental, replacement, emporium, and buffet, Auster (2016) suggests that supplemental model and replacement model are seemingly the most relevant models of blended learning. The supplemental model seems to fit Thorne's interpretation of blended learning while the replacement model suits the Garrison and Vaughan's.

\subsection{Process approach to writing}

Zemach and Rumisek (2005) state that to create a good piece of writing a writer must go through several steps of the writing process. This process, which is called the process approach to writing, includes the steps of pre-writing, drafting, reviewing, and revising (Badger \& White, 2000). Unlike the product approach which emphasizes on form, this process approach focuses on the facilitation of students' writing. The role of a teacher is to guide learners through the writing process to develop strategies for generating ideas, drafting, and refining ideas (Hyland, 2003). He adds that this could be reached through providing pre-writing activities to generate ideas, brainstorming, and outlining.

\section{Methodology}

The case study was used as the research method in this study, which was conducted at the English Education Department of a university in Indonesia from May to July 2018. One lecturer and six undergraduate students of a paragraph writing class were purposively chosen as the participants. The six students were selected as the respondents among 27 students based on their level of writing competence; high, medium, and low, where each level was represented by two students. Observations, 
interviews, and document analysis were used as the techniques for collecting data. The observations were conducted both in the classroom and on the online platform to reveal the instructional activities taking place in the two learning modes. The interview to the lecturer was carried out to probe the teaching and learning activities in the blended paragraph writing course, while the interviews to the six students were conducted to confirm the information gathered from the lecturer using open ended questions. Meanwhile, the document analysis was intended to get the supporting data from several sources, such as syllabus and lesson plans. Two techniques were used to obtain the trustworthiness of data, namely triangulation and member checking. The triangulation in this study involved checking the information collected from different methods, namely observations, interviews, and document analysis, while member checking was done by taking the conclusion or information back to the participants so that they could determine the accuracy of the conclusion.

Data were then analyzed using the Miles and Huberman's interactive model (2014). Three major steps of the analysis consist of data condensation, data display, and drawing and verifying conclusions. Data condensation involves the process of selecting, focusing, simplifying, abstracting, and/or transforming the data from field notes, interview, documents, and other empirical materials. Data display is a compressed assembly of information that allows conclusion drawing and action, helping the researcher understand what is happening and to do something either to analyze further or to act. Drawing and verifying conclusions are carried out from the onset of data collection by identifying patterns, explanations, and causal flows. The three steps are interwoven before, during, and after data collection in parallel form.

\section{Findings and discussion}

The paragraph writing course was an introductory to writing course series. The series consisted of Basic Writing, Paragraph Writing, Essay Writing, and Academic Writing. This 2-credit university course was the prerequisite course for Essay Writing and was offered in semester four. The blended learning approach used in the course involved the activities in face-to-face learning settings which were regularly conducted once a week for sixteen meetings and supplemented with the activities on online learning platform. It indicated that the supplemental model of blended learning was used in this paragraph writing course.

Schoology, a learning management system, was used as the online learning platform in the course. The syllabus and materials were uploaded on the online learning platform covering the course topics: the elements of a paragraph, process of paragraph writing (pre-writing), process of paragraph writing (writing supporting sentences), unity, coherence, descriptive paragraph, process paragraph, classification paragraph, definition paragraph, comparison-contrast paragraph, cause-effect paragraph, and opinion paragraph. The materials were uploaded before classroom meetings to allow students to pre-read the materials. 


\subsection{Blended learning activities}

There were ten main learning activities identified in the blended paragraph writing course, five activities on Schoology (online) and five activities in the classroom (faceto-face).

1) Uploading materials

Before face-to-face meetings, the course materials were uploaded on Schoology. In addition to enabling students to preview the materials that were going to be discussed in the classroom, the uploading was intended to make the materials accessible anytime and anywhere. Students could read or download them from their mobile devices, such as smartphone, laptop, or tablet. If students pre-read the material and become more prepared, the classroom time can be used for deeper analysis and discussion (Bowyer, 2017) rather than for lecturing. From the interview, however, it was found out that most students did not pre-read the materials. Instead, they preferred listening to the lecturer's explanation first before reviewing the materials afterward. It indicated that the lecture-based learning was still favored by the students. Although the time for lectures in blended learning is not eliminated, Garrison and Vaughan (2008) emphasize that the major goal of blended learning is "to reduce lecturing while increasing inquiry and discourse" (p. 72). To engage students with the prereading activity, Garrison and Vaughan (2008) suggest providing students with online follow-up quizzes, self-assessment, survey, or discussion forum so that students will read the material to accomplish the tasks.

2) Online quizzes

Online quizzes in this paragraph writing course were provided after the topics were discussed in face-to-face sessions. There were three online quizzes given during the course, namely the quizzes for identifying the topic sentences, paragraph unity, and transition signals. The quizzes were intended to strengthen what students already learned in the classroom and to be used as the students' self-assessment. Each quiz could be retaken multiple times during a certain time until the students attained the desired score. In her study, Davis (2018) reveals that such repeatable quizzing can improve knowledge retention and student motivation. Figure 1 shows the screenshot of a quiz.

3) Online writing assignments

When the course topics were about the types of paragraphs (descriptive, process, classification, definition, comparison-contrast, cause-effect, and opinion paragraphs), the lecturer assigned students to write a paragraph each week based on the type of a paragraph already learned in the classroom. The writing assignments were submitted or conducted on Schoology. The online writing assignments were done outside classroom hours to provide students with plenty of time to implement the steps in the writing process to produce good paragraphs. From the interviews, students admitted that this activity helped them a lot in improving their writing skill. The students had one week to complete the assignment before the following classroom meeting. These 
paragraph writing assignments were not graded but used for student portfolios. A study conducted by Bridge and Appleyard (2008) revealed that students found online assignment submission time-saving and paperless. Macdonald (2008) also asserts that online word processors make writing easier.

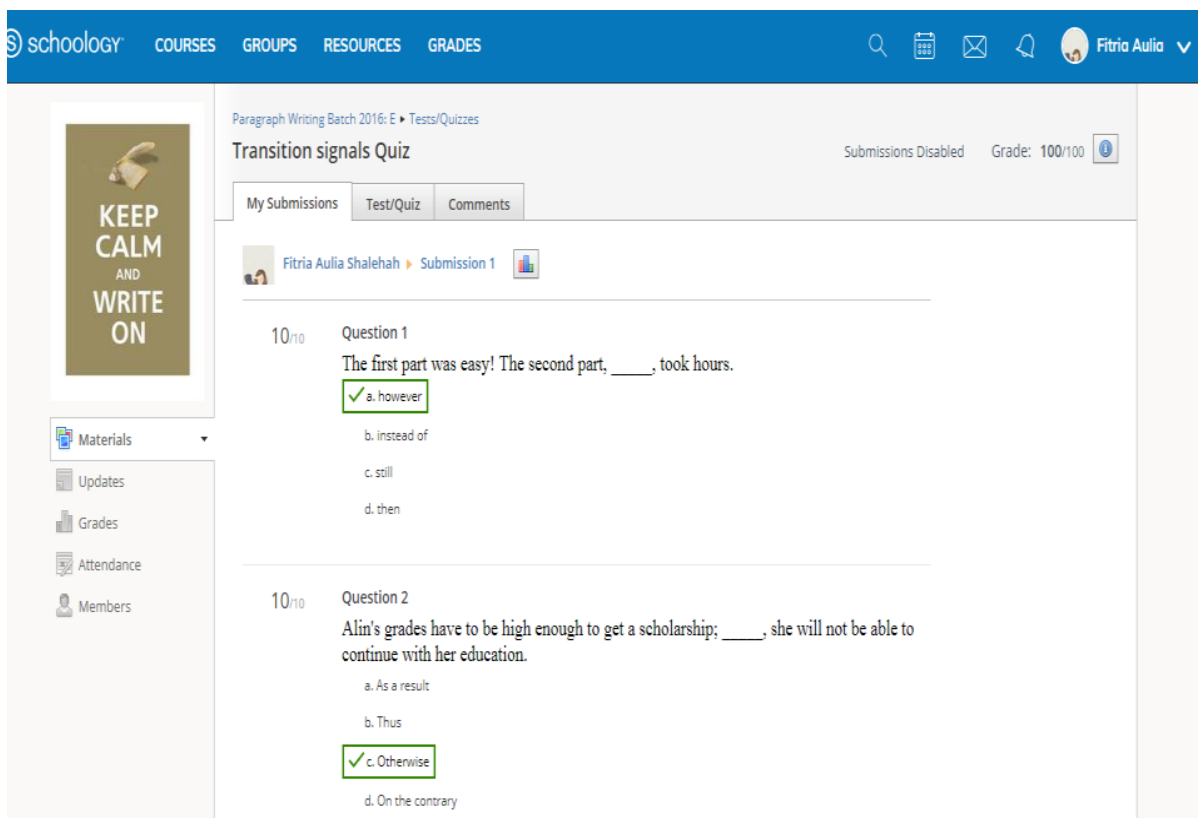

Figure 1. A quiz on Schoology

\section{4) Displaying the assignments}

The writing assignments on Schoology were not submitted on the "Submission" tool that would be directed to the lecturer's page but posted on the "Updates" page where all members could see and read. The "Updates" page is like the wall on Facebook, which is equipped with space for comments and other text-rich editor tools. By displaying the assignments on Schoology, the lecturer wanted to motivate students to write and allow them to learn from each other's pieces of writing. Berger (2003, as cited in Ebner, 2016) suggests that making work public to student's peers could increase student motivation and engagement. Figure 2 shows a screenshot of students' pieces of writing displayed on Schoology.

5) Online feedback

The comment section on the "Updates" page where the writing assignments were posted could be used as the space for giving online feedback. The feedback could be appraisal comments or corrective feedback. Although the lecturer already asked students to pass their comments on their friends' pieces of writing, only a few students give comments to their friends' work since it was not compulsory. Some students, however, showed their "like" by clicking the "like" button. That students are hesitant giving online feedback is also admitted by Jensen (2016) in his study. Therefore, if it is considered necessary to have online feedback, such as for peer-review activity or 
for increasing student-to-student interaction, the activity should be made compulsory.

Fitria Aulia Shalehah

There are many traditional foods in Indonesia, one of them is Apam. Apam is a cake which made from rice flour, yeast, coconut milk, and sugar. Its shape is circle and cooked on coals or firewood. There are a lot of kinds of Apam around Indonesia, but in South Kalimantan the most popular Apam is Apam Barabai. Barabai is the capital city of Hulu Sungai Tengah regency, one of the regency in South Kalimantan. There are two colors of Apam Barabai, one is brown and the other one is white. The brown one is made from palm sugar, so you can taste and smell palm sugar in it. If you don't like palm sugar, you can choose the white one which made from sugar. You can find Apam Barabai around Barabai, It cost around Rp5.000,00 per pack. One pack of Apam Barabai consist 8-10 Apam. If you come to Barabai, don't forget to buy Apam Barabai!

Tue May 8, 2018 at 5:44 pm Comment - Like

(2) 6 people liked this

muhammad akbar sani

Eilin ins this one hhiii

Tue May 8, 2018 at 7:32 pm · Like

Write a comment

Habibah Munawaroh

One word that you might be often heard in Indonesia is baper. Baper is one of Indonesian slang that stands for Bawa Perasaan which means a person who is emotional. It could also mean a situation when some events made you feel very emotional and remember about the past things that were very personal for you. You will find this term in some various occasions. for example someone will say this...

- Show More

Tue May 8, 2018 at 6:59 am Comment · Like

(2) 4 people liked this

Write a comment

Figure 2. A display of students' writing assignments on Schoology

\section{6) Lecturing}

A brief lecture was delivered by the lecturer to introduce a new topic each week in the classroom. The lectures were intended to explain new concepts such as the characteristics of a paragraph type, but the lectures were maintained brief. Although lecturing is considered a relatively ineffective teaching method (Knight, 2005), there are some merits of lecturing, one of which is providing guidelines on how to learn a topic and what to learn (Brown \& Manogue, 2001). Garrison and Vaughan (2008) emphasize that the lecturing time in blended learning should be reduced and replaced with interactive and collaborative learning activities.

7) Class discussion

Class discussion was one of the dominant activities in the classroom. After introducing the day topic, the lecturer showed the class a model paragraph of a new paragraph type and asked students to identify the paragraph for the topic sentence, supporting sentences, and concluding sentence. The results of the exercises were then discussed together in the class. In this session, students were not only discussed the results but they could also ask questions related to the topic. It is in line with what Stein and Graham (2014) state that the class discussions give "opportunities for teachers to direct student exploration of a topic, and for students to test ideas, ask questions, and debate points" (p. 150).

8) Pair work/group work

The exercises in the classroom were mostly done in pairs or groups, such as 
identifying the elements of a paragraph model and making the outline for their own paragraphs. The group work can increase the interaction between students and the lecturer and among the students themselves (Macdonald, 2008). The collaborative learning in groups also results in stronger solutions and supports sharing for better learning (Sansivero, 2016). The climate for collaborative learning is strongly encouraged in the practices of blended learning (Garrison \& Vaughan, 2008).

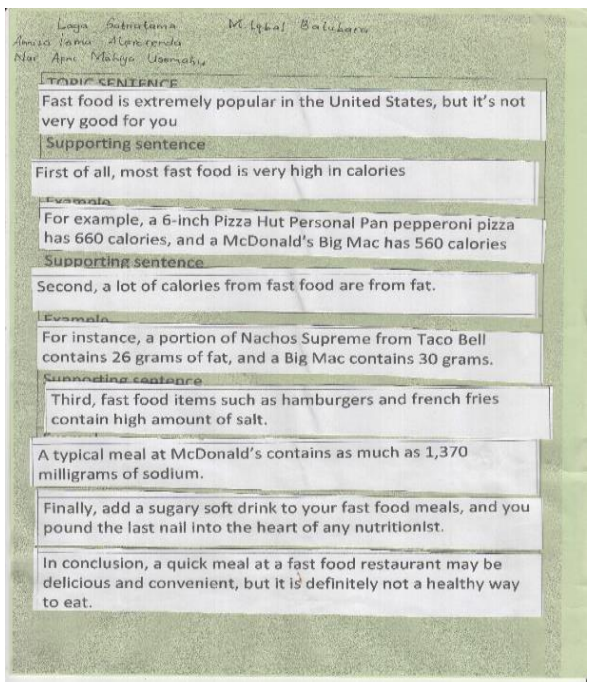

Figure 3. A sample of students' group work (a paper-glue activity)

\section{9) Teacher-student conferencing}

This face-to-face conferencing is an activity to give feedback on student writing. The writing assignments that were previously submitted and displayed on Schoology would be discussed in class and the lecturer gave some feedback on students' assignments in general without giving grades on each student' work. Giving grades can be discouraging, so it is better to provide actionable feedback that students can use for the following writing exercises (Garrison \& Vaughan, 2008). Spencer (2015) states that the teacher-student conferencing on students' work could help students in self reflection, provide advice, and review the mastery (Spencer, 2015).

10) Portfolios

The students had to print out and gather all writing assignments posted on Schoology to make writing portfolios. The portfolios were used to see students' writing progress and used as part of the summative assessment. Hyland (2003) argues that the portfolio project can reduce student anxiety in assessment because the student work was the refined work after receiving feedback from the instructors or peers. In this paragraph writing course, portfolio assessment was not the only assessment, middle and final tests were still used to assess students' paragraph writing performance. It is in line with the study by Birgin and Baki (2007) that the traditional assessment methods are still needed in addition to the alternative method, such as portfolio, to get more reliable information about students' performance. 


\subsection{Students' paragraph writing performance}

In order to find out the extent to which the use of blended learning in the paragraph writing course affected students' paragraph writing performance, the students' scores of the final test were analyzed. In the final test students were asked to write two paragraphs from several types of paragraphs they could choose with the topics already provided. The scores of the final test were classified into letter grades; $\mathrm{A}^{+}$(the average score from 90-100), A (80-89.9), $\mathrm{B}^{+}$(75-79.9), B (70-74.9), $\mathrm{C}^{+}$(65-69.9), and $C$ (60-64.9). Among 27 students, five students got an $A^{+}$, more than a half get an $A$, four got $\mathrm{B}^{+}$, and only one student got a $\mathrm{B}$ which was the lowest grade in the class. This result can be clearly illustrated in the following bar chart.

\section{Student Grades}

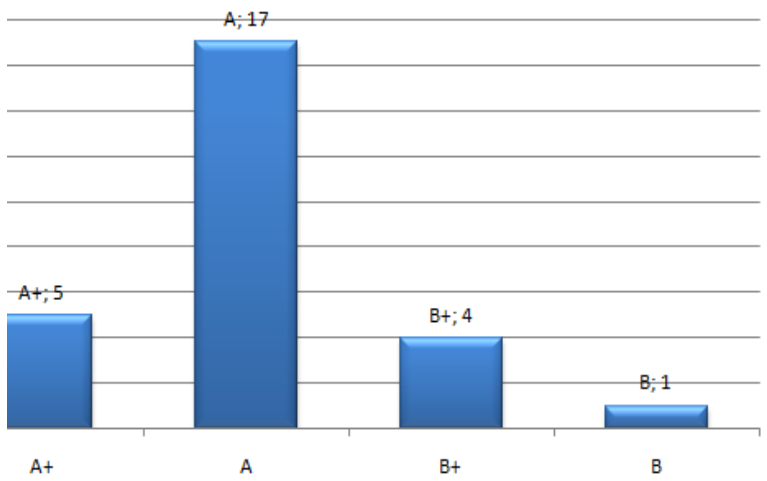

Figure 4. A bar chart of students' grades for paragraph writing

It can be seen from the bar chart that most students got an A, which is considered a very good grade. Moreover, the lecturer conveyed her satisfaction over students' writing performance by saying,

I teach them outlining, and the techniques for brainstorming such as clustering and listing, with the intention that they can apply the techniques when they need to write. In the middle and final tests, they applied brainstorming and then outlining; they organize (ideas), the step after (finding) a topic sentence. Many students made improvements in their writing skills compared to what they did in early days.

This indicates that the use of blended learning had a positive effect on the students' paragraph writing performance. The classroom time was efficiently used for the exploration of paragraphs and techniques of writing process, and the writing activity were done on Schoology. It is in line with the study conducted by Ghahari and AmeriGolestan (2013) that a blended learning method has created a more desirable condition to enhance students' writing performance.

\section{Conclusions}

The blended learning in the paragraph writing course included ten main activities, five in the face-to-face setting and five on the online platform. Some activities apparently need to be enhanced, such as a need for online follow-up quizzes before face-to- 
face meeting to engage students into pre-reading and a required activity for students' commentary on each other's work to increase student-to-student interaction. The activity that students found very helpful was the weekly online writing assignments because it encouraged them to practice writing regularly and it was more convenient to accomplish the writing assignments online. The analysis of students' final test scores described that the use of blended learning in the paragraph writing course affected the students' writing performance in a good way.

\section{References}

[1] Auster, C, J. (2016). Blended learning as a potentially winning combination of face-to-face and online learning: an exploratory study. Teaching Sociology. 44(1), 39-48.

[2] Badger, R. \& White, G. (2000). A process genre approach to teaching writing. ELT Journal, 54(2), 153-160.

[3] "Best IELTS preparation" (2013). The Importance of Paragraphs in IELTS Writing Retrieved from http://www.bestieltsonline.com/paragraphs-in-ielts-writing-2/

[4] Birgin, O. \& Baki, A. (2007). The use of portfolio to assess student's performance. Journal of Turkish Science Education, 4(2), 75-90.

[5] Bowyer, J. \& Chambers, L. (2017). Evaluating blended learning: bringing the elements together. Research Matters: A Cambridge Assessments Publication, 23, 17-26.

[6] Bridge, P. \& Appleyard, R. (2008). A comparison of electronic and paper-based assignment submission and feedback. Brittish Journal of Educational Technology, 39(4), 644650. Doi: 10.1111/j.1467-8535.2007. 00753.x

[7] Brown, G., \& Manogue, M. (2001). Refreshing lecturing: a guide for lecturers. Medical Teacher, 23(3), 231-244. doi: 10.1080/01421590120043000

[8] Bryson, S. (2014). How to structure a paragraph in an academic essay. Retrieved from https://www.scribbr.com/academic-essay/how-to-structure-a-paragraph-in-an-academic-essay/

[9] Davis, K. (2009). Improving motivation and knowledge retention with repeatable lowstakes quizzing. American Society for Engineering Education. 1-7.

[10] Ebner, H. K. (2016). Work conferences and student engagement. Masters of Arts in Education Action Research Papers. Paper 153.

[11] Epignosis LLC (2014). E-learning; concepts, trends, applications. Retrieved from http://www.talentlms.com/elearning-101-jan2014-v1.1.pdf

[12] Garrison, D. R. \& Vaughan, N. D. (2008). Blended learning in higher education. John Wiley \& Sons, Inc. San Francisco-USA.

[13] Ghahari, S., \& Ameri-Golestan, A. (2013). The effect of blended learning vs. classroom learning techniques on Iranian EFL learner's writing. International Journal of Foreign Language Teaching and Research, 1(3), 77-86.

[14] Hyland, K. (2003). Second language writing. New York: Cambridge University Press.

[15] Jensen, E. B. (2016). Peer-review writing workshops in college course: students' perspectives about online and classroom-based workshops. Social Sciences, 5(72), 1-17. Dopi: $10.3390 /$ socsci5040072.

[16] Knight, J. K., \& Wood, W. B. (2005). Teaching more by lecturing less. Cell Biology Education, 4(4), 298-310. doi: 10.1187/05-06-0082

[17] Liu, M. (2013). Blended learning in a university EFL writing course: description and evaluation. Journal of Language Teaching and Research, 4(2), 301-309. Doi: 10.4304/jltr.4.2.301-309.

[18] Macdonald, J. (2008). Blended learning and omline tutoring: planning leaner support and activity design ( $2^{\text {nd }}$ ed.). Hampshire, England: Gower Publishing Limited. 
[19] Miles, M. B., Huberman, A. M., \& Saldana, J. (2014). Qualitative data analysis: a methods sourcebook ( $3^{\text {rd }}$ ed.). California, USA: SAGE Publications, Inc.

[20] Sansivero, G. (2016) Challenges \& advantages of collaborative learning: developing workforce readiness in students. SEEN (SouthEast Education Network) Magazine. http://www.seenmagazine.us/Articles/Article-Detail/ArticleId/5613/CHALLANGESamp-ADVANTAGES-OF-COLLABORATIVE-LEARNING

[21] Savage, A. \& Shafiei, M. (2007). Effective academic writing 1: the paragraph. New York: Oxford University Press.

[22] Spencer, J. (2015). The power of student conferencing. Retrieved from http://www.spenerauthor.com/the-power-of-student-conferencing/

[23] Stein, J. \& Graham, C. R. (2014). Essentials for blended learning: a standards-based guide. Routledge. Third Avenue-New York.

[24] Thorne, K. (2003). Blended learning; how to integrate online and traditional learning. London, UK: Kogan Page Limited.

[25] Tuomainen, S. (2016). A blended learning approach to academic writing and presentation skills. De Gruyter, 3(2), 33-55.

[26] Twigg, C. A, (2003). Improving learning and reducing costs: new models for online learning. Educause Review, 28-38.

[27] Zemach, D. E. \& Islam, C. (2007). Paragraph writing: from sentence to paragraph. London: McMillan.

[28] Zemach, D. E. \& Rumisek, L. A. (2005). Academic writing: from paragraph to essay. Oxford: McMillan. 